\title{
Theory of Planned Behavior Influences Online Shopping Behavior
}

\author{
Felix Sutisna ${ }^{1}$, Tessa Handra ${ }^{2}$ \\ Universitas Multimedia Nusantara \\ felix.sutisna@lecturer.umn.ac.id ${ }^{1}$, tessa.handra@lecturer.umn.ac.id ${ }^{2}$
}

\section{To cite this document :}

Sutisna, F., \& Handra, T. (2022). Theory Of Planned Behavior Influences Online Shopping Behavior. Aptisi Transactions on Management (ATM), 6(1), 20-28.

DOI :

https://doi.org/10.33050/atm.v6i1.1691

\begin{abstract}
Nowdays many factors influence shopper interested in buying merchandise through ebusiness, such as promotions made by e-business companies, speed and less time, fast payment transactions and low cost, and marketing mix. Most shopper utilize e-business to shop for food products, electronics, logistic (such as gojek/grab/uber, travel) and others. The application of ebusiness can not be separated from the expertise and knowledge of the public in using the internet and computer systems. However, Indonesian people's awareness of e-business is still low, many people do not know how to utilize it. This is due to low internet infrastructure factors, poor telecommunication facilities. This is still a barrier to the interest of the people of Indonesia to testify online. In addition, shopper confidence and trust in the security of e-business can affect someone to shop online. In explaining the factors that impact on shopper conduct to utilize e-business utilized theory of planned behavior approach. The theory of Planned Behavior (TPB) has supported the prediction of many different conducts of people. TPB shows that determining conduct is one's purpose. This study aims to analyze the impact of perceived behavioral control, subjective norm, and attitude, on purpose to shop online and its impact on online shopping behavior. Exogenous variable research is perceived behavioral control, subjective norm, and attitude. The variables of endogenous research are intended to shop online and online shopping behavior. The research sample of 100 respondents was shopper who shopped in e-business X. Data collection method using questionnaires. Data analysis method using SEM PLS.
\end{abstract}

\section{INTRODUCTION}

The development of IT today has a big impact on the business world [1]. A competitive company is one that can use technology effectively. The position of the internet as a business tool is becoming increasingly important. The use of the internet has grown very rapidly, especially in the commercial world, with mid-sized companies taking advantage of the internet to advertise their wares as well. [2]. E-business is defined as the use of technology to promote commercial rivalry in the marketing of commodities. [3].

E-business has an important role in serving consumers, growing regionally, responding to competitive challenges, and reducing operational costs [4]. There are several understandings about e-business, among others e-business is a process that buyers do in buying and selling various goods electronically from companies to other companies by using computers as intermediaries for business transactions conducted [5]. Trades run through the website are known as e-business. E-business is a mechanism of buying and selling using internet technology with cyberspace as a place to meet buyers and sellers. E-business can be interpreted as a way of selling and buying online or direct selling that utilizes the facilities of international computer network connection by implementing a website that can provide a "get and deliver" service. The implementation of e-business is also one of the crucial things to support a prosperous sale of goods from the company.

Many factors make buyers interested in buying goods through e-business, such as promotions made by e-business companies, speed and save time, fast payment transactions and 
can shrink, and marketing mix. Most buyers use e-business to shop for food products, electronics, logistic (such as gojek/grab/uber, travel) and others. The reason they use e-business goods is that they use them practically because the cost and location details are clear, the delivery costs are free, the goods selection is diverse, and the goods can be paid for by shrinking. Therefore, many buyers turn to e-business and many factors impact the buyer's intention to get goods through e-business [6].

The use of e-business cannot be separated from the expertise and knowledge of the community in using the internet and computer systems [7]. But Indonesian people's awareness of e-business is still low, many people do not know how to use it. This is due to low internet infrastructure factors, poor telecommunication facilities. This is still a barrier to the interest of the People of Indonesia to testify online. In addition, buyer confidence in the security of e-business can affect someone online shopping [8].

In explaining the factors that impact on buyer conduct to use e-business used theory of planned behavior approach [9]. The Theory of Planned Behavior (TPB) has aided in the prediction of a wide range of human actions. The TPB also demonstrates that guaranteeing conduct is a person's aim. Subjective orientations and norms impact a person's conduct through intentions. People's total judgment or assessment of emotional and instrumental conduct is referred to as attitude [10]. Subjective norms may also be used to measure the social pressure on a person to engage in or refrain from engaging in a behavior. TPB also attempts to anticipate non-random behavior by including top management's perceptions of performance as additional determinants of intention and action [9]. Perceived behavioral control (PBC) is a person's introduction to the extent to which performance is easy or difficult and maintains consistent motivation. [9].

SME's (Small and Medium Enterprises) is an important element of Indonesia's economic development. This is because SMEs have been absorbed into a huge workforce that is close to the people. Marketing is the primary issue that SMEs confront. Opening additional branches, participating in exhibits, creating and spreading brochures, and other traditional marketing tactics come with a large price tag. The advancement of the internet has proven to be an effective way of creating new model marketing channels for SMEs. E-business is a type of internet-based marketing and sales service. Buyers can quickly spot superior items and deal based on them. Ebusiness is a type of marketing and sales that takes place through the internet. Buyers may quickly see better items and trade based on the goods they have chosen to purchase at any time and from any location.

According to the above description, the purpose of this study is to see if attitudes, subjective norms, and perceived behavioral controls influence a buyer's desire to purchase online, and then to see how that intention is translated into customer behavior when shopping online. This study's chart or conceptual framework is shown in Figure 1.:

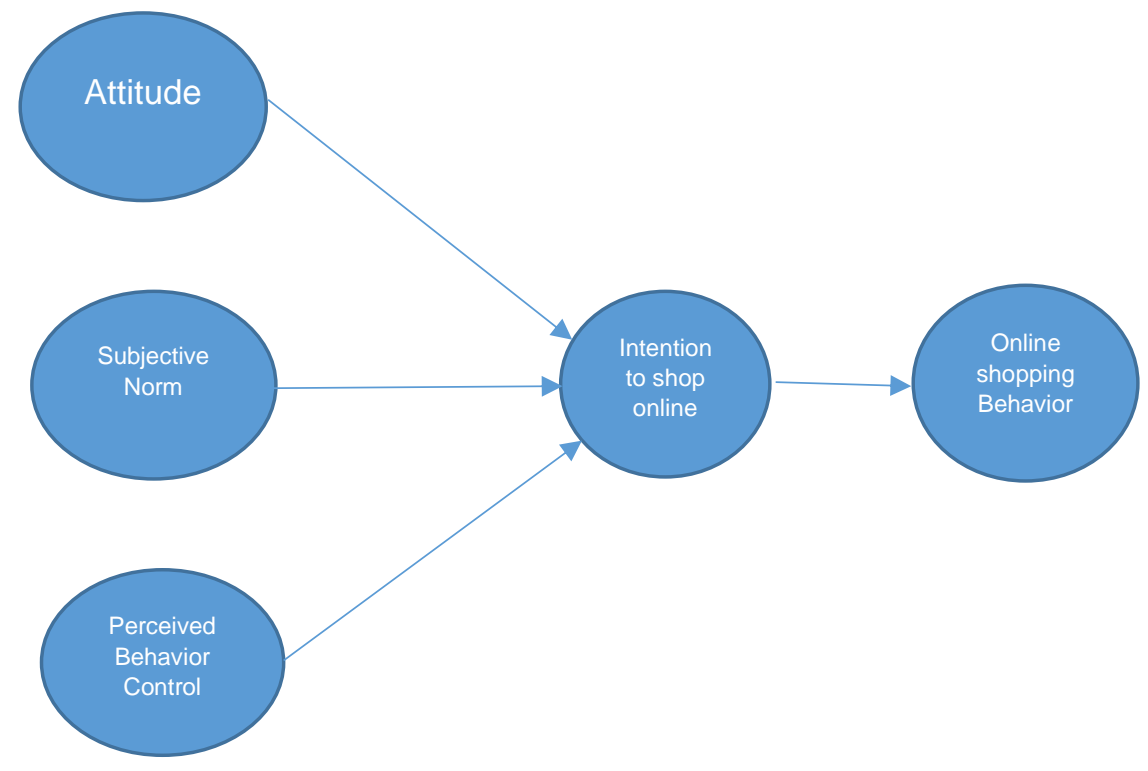




\section{THEORETICAL FRAMEWORK}

\section{Figure 1. Research Model}

\section{Theory of Planned Behavior (TPB)}

This hypothesis is based on the idea that a person's ideas can influence his behavior. The belief perspective is used by combining the characteristics, qualities, and specific aspects of information to produce behavioral goals. Intention is a conscious or unconscious decision to perform in a certain way as a result of a desired medium or stimulus. The development of a person's behavior begins with this goal. Any action that requires a plan can be visualized using the idea of planned behavior. [9].

The theory of planned behavior is a refinement of the theory of planned behavior. According to the theory of reasoned action, the desire to perform a particular action is motivated by two factors: subjective norms and attitudes toward behavior. [11]. A few years later, [9] added one factor that is person behavioral control or perceived behavioral control. The existence of these factors turns reasoned action theory into Planned behavior theory.

The theory of planned behavior consistently supports the idea that humans are rational entities that use all available knowledge. People consider the consequences of their actions before deciding whether or not to engage in a particular behavior. The theory of planned behavior analyzes customer preferences, subjective norms, and perceived behavioral control of buyers [12].

According to planned behavior theory, conduct orientations are a critical point that can estimate an action, even though it is important to take one's orientation into account while evaluating subjective standards and gauging the management of one's conduct. If one has a good attitude, has support from others, and perceives that there are no impediments to behavior, one's intention to behave will be higher [9]. When a person has a favorable attitude toward stock investing and is surrounded by people who support him, and there is a sense of comfort since there are no barriers to investing in stocks, one's desire to invest in stocks increases.

The theory of reasoned action is a model used to predict interests and behavior [13]. According to the idea of reasoned action, a person's behavior is determined by his interests, but the desire to behave is primarily determined by attitudes and subjective standards. On the other hand, the way one thinks about the repercussions of one's actions has a significant influence on one's subjective attitudes and standards. Buyer behavior and interests are impacted by both internal and external influences (social environment). External influences are represented in the impact of others (subjective standards) on conduct, whereas internal factors are reflected in one's orientation. A model is needed to study subjective attitudes and norms, one of which is Fishbein's multi-attribute model.

The theory of reasoned action assumes that almost all conduct under one's progress management performs a particular action. However, the fact is that most of a person's behavior is beyond his or her control. Some behaviors, such as those relating to competence, ability, knowledge, and excellent planning, are lacking. In other cases, there may be external hurdles, such as time or opportunity, that must be overcome in order to attain the goal. The theory of reasoned action's model evolves into a theory of planned behavior. In 1967, the Theory of Reasoned Action (TRA) was created. Controlling one's behavior. When there are no barriers to expressing a behavior, one has full management. Otherwise, in extreme circumstances, there may be no way to manage behavior due to a lack of opportunities, resources, or abilities.

The degree to which a person believes he has control over the appearance or absence of behavior is referred to as perceived behavioral control. Even if they are positive and believe that those who are important to them would approve, people are less likely to have a strong intention to show a certain behavior if they do not have the chance to do so. When the impression of management and the actual management of a person over conduct are in sync, a straight link from behavioral control to behavior is predicted to emerge. Furthermore, the idea was updated and extended upon by [11] . In 1980, this theory was used to study human behavior and to develop more appropriate interventions In the 1980s, this theory was used to consider human behavior and to promote more appropriate interventions. In 1988, another behavioral control was added to the action model argued to exist, later named Planned Behavior Theory (TPB).

Experts use numerous research to make accurate forecasts about consumer behavior. The theory of planned behavior is a development of the theory of reasoned action that seeks to solve difficulties that aren't completely within the control of someone who isn't fully versed in the theory of reasoned action. The foundation of the Theory of Planned Behavior remains behavioral 
intention components, but determinants of intents include features of perceived behavior control as well as attitudes and subjective standards. However, perceived behavioral control is thought to have direct or indirect consequences in predicting consumer behavior. The three components, namely attitudes, subjective norms, and perceived behavioral control, interact and form determinants for interests, which decide whether or not the action in issue will be carried out.

The components in Theory Planned Behavior are [9]: 1. The mindset of the buyer The first variable of behavior is one's attitude. An attitude is good or negative thinking that is used to demonstrate a certain behavior. Behavioral beliefs are the term for these kinds of ideas. When a person positively evaluates a behavior, he or she will want to engage in it. People's attitudes are shaped by their perceptions of the consequences of expressing behavioral ideas, which are weighed and confirmed by the results of a risk assessment (outcome assessment). Such attitudes are linked to subjective standards and perceived behavioral control and are thought to have a direct influence on behavior. Subjective Norms are the second type of norm. A subjective norm is considered to be the function of thinking that is accepted or rejected by a specific individual in order to display conduct. Thoughts that conform to subjective standards (normative beliefs). If it is seen that another important person believes that he or she should do so, a person will plan to do so.

\section{Intention to shop online}

Intention to shop online according to [14] is a tendency of buyers to choose a brand or take action related to purchases as measured by the level of likelihood of buyers making purchases online. According to [15] intention to shop online is how likely buyers are to purchase a brand or how likely buyers are to move from one brand to another online. It is suggested that the desire to purchase online is a notion that comes from a feeling of curiosity and wants for an item or service that is expected to be available online [16].

\section{Attitude}

[17] explain attitude is a consistent assessment, feeling, and the tendency for a person's likes or dislikes of objects or ideas. [15] interprets the buyer's attitude (either positive or negative) towards a target after evaluating the object. Completion of the object being evaluated will form more and more attitudes. Furthermore, the attitude function is divided into several parts, including adjustment functions, protective ego, value expression, and knowledge expression. The buyer's attitude is a response to the advertising message recorded by the buyer. Another meaning of attitude towards behavior is a person's good or bad feeling when they are asked to perform a certain action. When analyzing actions in a problem, one's attitude is the level of self-assessment at which one feels favored or disliked [9].

Attitude towards behavior is a tendency to respond to things that are favoured or that are not favoured on an object, person, institution or event [9]. Attitudes towards behavior are considered the first variables that affect the intention of behaving. When a person positively values an action, he has the will to do a particular deed.

As a result of conduct, ideas (behavioral beliefs) impact one's perspective on behavior. The strength of a person's ideas, as well as the evaluation of the consequence, are included in their thoughts. Views on behavior are thought to have a direct influence on the desire to behave, which is then interpreted by behavioral perception control and subjective norms [9].

\section{Subjective Norm}

[11] Define that subjective norm as a person's perception of whether people are crucial to person thinking conduct should be done. Perception is a process that involves entering messages or information into the human brain. [17] define subjective norm as a person's perception that comes from social pressure to do or not perform certain conducts. Contributions of opinions from each referral are given weight.

Subjective norms are an acknowledgement of social insistence on showing a special orientation [18]. Subjective norms are advantages that have a foundation for a belief known as normative belief. A normative belief is a notion in a person's or group's understanding or disagreement that influences a person's behavior. Some behaviour's most powerful social 
influences come from partners, family, co-workers, relatives, and other people involved with the activity.

[11] say that social power is part of the subjective norm. The incentives or penalties transmitted by the person to others, the person's affection for others, the degree to which the person is regarded as an expert, and the person's wishes make up the social power described above. Normally, according to [19], it tends to be a person to have an understanding that the person suggests to carry out a conduct then the social pressure felt will be greater, on the contrary, if it gives suggestions not to carry out a conduct then the perceived social pressure tends to decrease.

\section{Behavior Control}

That controlling behavior refers to a person's understanding of his ability to perform certain behaviors [9]. In other words, behavioral control refers to how much a person believes they have control over whether or not they display a particular behavior. A variety of ideas regarding the existence of variables that might assist or complicate the performance of the exhibited behavior influence behavioral control. All human behaviors or activities, whether immediately observable or not, are classified as behavior. A person's response or reaction to an external stimuli is referred to as conduct [17].

Perceived behavioral control is a measure of one's thinking in how simple or complex it is to carry out an action [20]. Behavioral control can also be interpreted as an understanding of the simplicity or complexity of actions based on previous experience and the obstacles that can be found in carrying out actions [21]. A person who has a supportive subjective attitude and norms in carrying out certain actions will rely heavily on the support of the perceived behavioral control that he has.

The existence of supporting factors provides an important role in terms of managing behavior control. Similarly, the fewer contributing factors a person perceives, the more difficult it is to understand one's own behavior [19]. A person who has a positive orientation, support from people around and at least barriers to conducting a behavior, then that person will have strong intentions compared to having a positive orientation and support from people around but many barriers are there to do such conduct.

\section{The effect of attitude on intention to shop online}

Attitude is the level at which a person has a positive or negative assessment of a particular conduct [9]. When buyers think that the use of e-business is not crucial, an attitude is formed that makes buyers do not intend to use e-business. On the contrary, if buyers think that the use of e-business is a necessity, then there will be a positive attitude, in addition, if buyers think that e-business can provide benefits to obtain more effective goods search and greater discounts then buyers will intend to use e-business [13]. Therefore, the research hypothesis:

$\mathrm{H} 1$ : attitude affects intention to shop online

\section{The Effect of subjective norm on intention to shop online}

The subjective norm is one's consideration as to whether another person thinks that someone needs to do so or not [9]. Buyer subjective norms for the use of e-business are formed from the surrounding environment. When other buyers in the neighborhood do not use e-business and still use direct shopping, subjective norms are formed that make buyers do not intend to use ebusiness. Conversely, if people around such as friends or family recommend using e-business, and the transaction process goes well then subjective norms are formed that make buyers intend to use e-business [13]. Therefore, the research hypothesis:

H2: subjective norm affects intention to shop online.

\section{The effect of perceived behavioral control on intention to shop online}

Behavioral control is a condition in which a person believes that an action is easy or difficult to perform under the management of a person [9]. When the use of e-business is difficult to use, then a behavioral control is formed that makes buyers do not intend to use e-business. Conversely, if buyers think that e-business is easy to use, a positive orientation will be formed [13]. Therefore, the research hypothesis:

H3: perceived behavioral control affects intention to shop online 


\section{The effect of intention to shop online on online shopping behavior}

Intention to shop online can produce online shopping behavior from the interests experienced by buyers. At the stage of interest, buyers realize that they like a particular goods and want to own the goods so that if the thought in the goods are positive it will lead to the decision to make a purchase conduct. Intention to shop online is a variable that affects conduct to shop online [13]. Supported on the description, the research hypothesis:

$\mathrm{H} 4$ : intention to shop online affects online shopping behavior.

\section{RESEARCH METHODOLOGY}

This study aims to analyze the impact of perceived behavioral control, subjective norm, and attitude, on intention to shop online and its impact on online shopping behavior. Exogenous variable research is perceived behavioral control, subjective norm, and attitude. The variables of endogenous research are intended to shop online and online shopping behavior. The research sample of 100 respondents was buyers who shopped in e-business X. Data collection method using questionnaires. Data analysis method using SEM PLS.

\section{Validity Testing}

Corrected convergent validity tests are declared valid if the loading factor value is greater than or equal to 0.3 . While discriminant validity is seen from the AVE value and declared valid if it is greater than or equal to 0.5 . The outcomes of the convergent validity test can be seen in the following figure:

Table 1. Outer Loading

\begin{tabular}{|c|c|c|c|c|c|}
\hline & Attitude & Intention to Shop Online & Perceived Behavioral Control & Shopping Online Behavior & Subjective Norm \\
\hline A1 & 0.949 & & & & \\
\hline A2 & 0.963 & & & & \\
\hline A3 & 0.951 & & & & \\
\hline ISO1 & & 0.987 & & & \\
\hline ISO2 & & 0.988 & & & \\
\hline ISO3 & & 0.981 & & & \\
\hline ISO4 & & 0.988 & & & \\
\hline PBC1 & & & 0.988 & & \\
\hline $\mathrm{PBC} 2$ & & & 0.985 & & \\
\hline PBC3 & & & 0.984 & & \\
\hline SN1 & & & & & 0.974 \\
\hline SN2 & & & & & 0.983 \\
\hline SN3 & & & & & 0.982 \\
\hline SOB1 & & & & 0.950 & \\
\hline SOB2 & & & & 0.890 & \\
\hline SOB3 & & & & 0.912 & \\
\hline
\end{tabular}




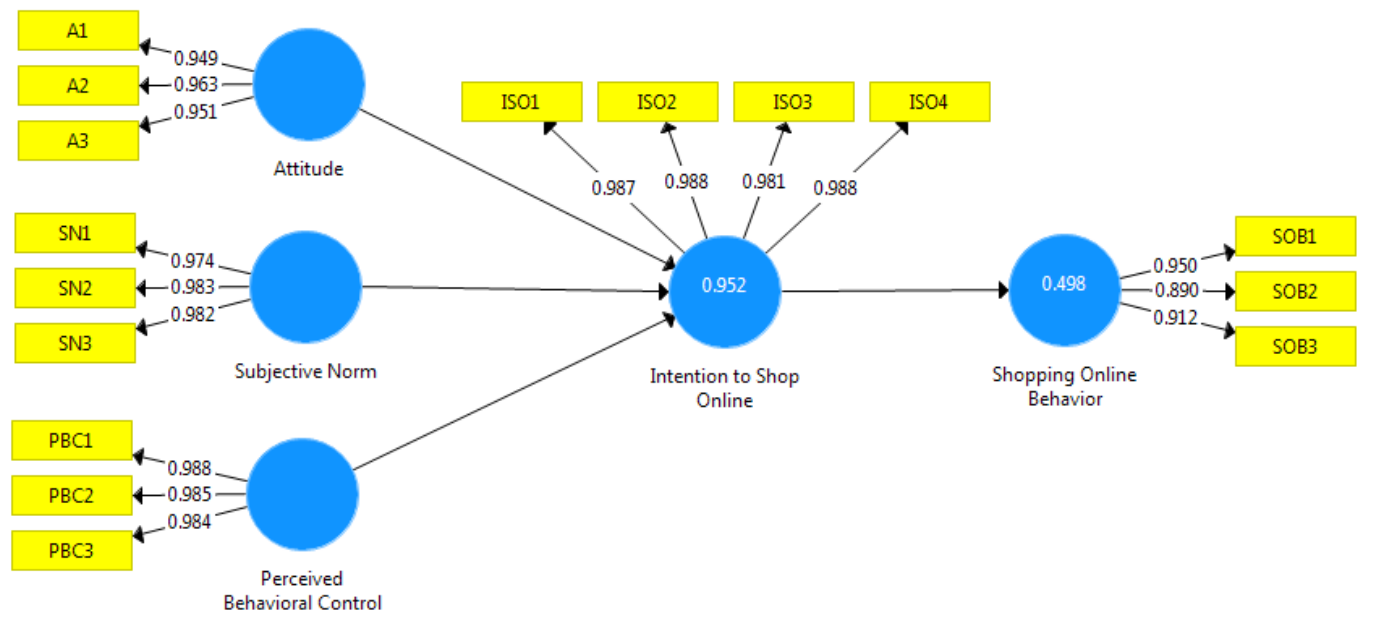

Figure 2. SmartPLS Output for Validity Test

The attitude statement item has the highest loading factor value of 0.963 and the lowest of 0.949. Subjective norm statement item has the highest loading factor value of 0.983 and the lowest of 0.974 . The statement item perceived behavioral control has the highest loading factor value of 0.988 and the lowest of 0.984 . The item intention to shop online statement has the highest loading factor value of 0.988 and the lowest of 0.981 . The online shopping behavior statement item has the highest loading factor value of 0.950 and the lowest of 0.890 . After being tested convergent validity is then tested discriminant validity by looking at the AVE value. Here is the Smartpls output:

Table 2. Average Variance Extracted (AVE) and Cronbach Alpha

\begin{tabular}{|l|r|r|r|r|} 
& Cronbach's Alpha & rho_A & Composite Reliability & Average Variance Extracted (AVE) \\
\hline Attitude & 0.951 & 0.951 & 0.968 & 0.910 \\
\hline Intention to Shop Online & 0.990 & 0.991 & 0.993 & 0.972 \\
\hline Perceived Behavioral Control & 0.986 & 0.986 & 0.991 & 0.972 \\
\hline Shopping Online Behavior & 0.906 & 0.912 & 0.941 & 0.842 \\
\hline Subjective Norm & 0.979 & 0.979 & 0.986 & 0.960 \\
\hline
\end{tabular}

According to table 2 the AVE value for each variable is greater than 0.5 so that all statement items are discriminantly valid. Instrument reliability testing is tested using Alpha Cronbach analysis. Alpha Cronbach is an average of all parts of a coefficient that may be the outcome of different ways of dividing scale items. According to table 2 the alpha-Cronbach value for each variable is greater than $0.7 \mathrm{so}$ it can be concluded that the statement item for each variable is reliable.

\section{Hypothesis Testing}

The following are the outcomes of SEM PLS analysis in the research analysis: 


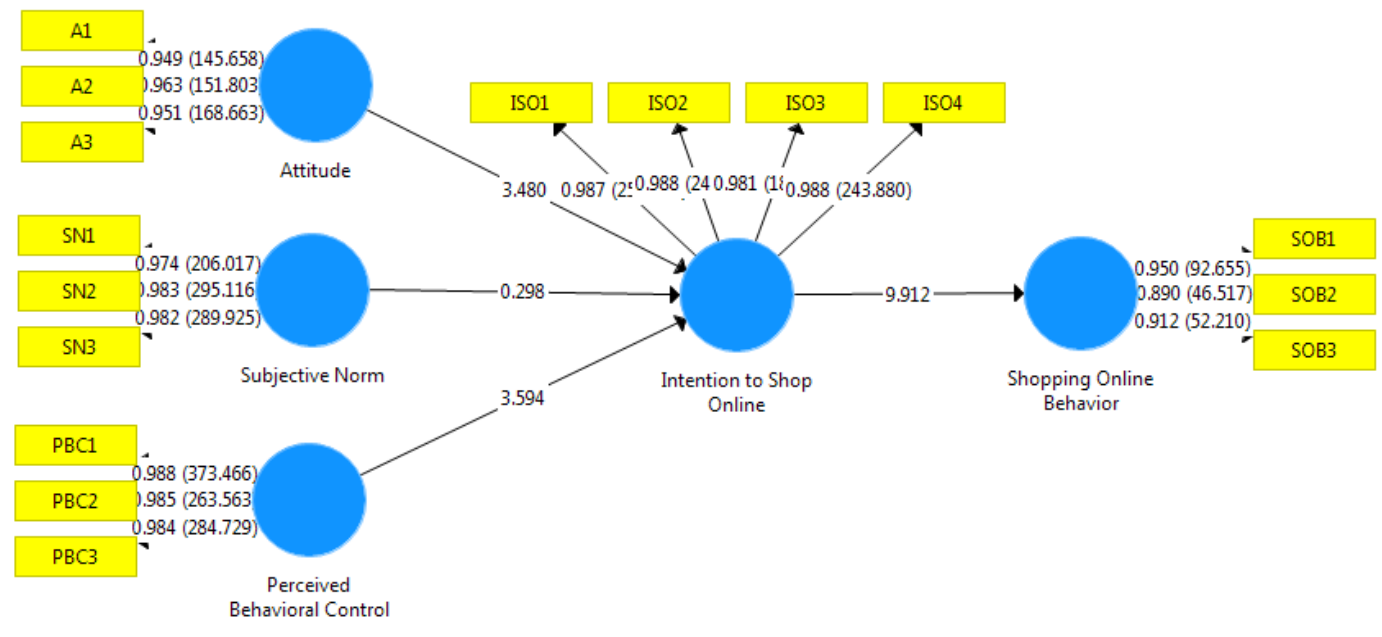

Figure 3. Output SmartPLS

Table 3. Coefficient

\begin{tabular}{|l|r|r|r|r|r|}
\hline & Original Sample (O) & Sample Mean (M) & Standard Deviation (STDEV) & T Statistics (|O/STDEV) & P Values \\
\hline Attitude -> Intention to Shop Online & 0.350 & 0.347 & 0.101 & 3.480 & 0.001 \\
\hline Intention to Shop Online -> Shopping Online Behavior & 0.705 & 0.709 & 0.071 & 9.912 \\
\hline Perceived Behavioral Control -> Intention to Shop Online & 0.589 & 0.573 & 0.164 & 3.594 \\
\hline Subjective Norm -> Intention to Shop Online & 0.046 & 0.000 & 0.000 \\
\hline
\end{tabular}

Table 4. Hypothesis Testing Summary

\begin{tabular}{|c|c|c|c|}
\hline Hypothesis & $\mathrm{t}$-value & p-value & Conclusion \\
\hline 1 & 3,480 & 0,001 & Significant \\
\hline 2 & 0,298 & 0,766 & Insignificant \\
\hline 3 & 3,594 & 0,000 & Significant \\
\hline 4 & 9,912 & 0,000 & Significant \\
\hline
\end{tabular}

According to Table 4. p-value for hypothesis 1 of $0.001<0.05$ means there is an attitude impact on intention to shop online. $p$-value value for hypothesis 2 of $0.766>0.05$ means there is no subjective norm impact on intention to shop online. The $p$-value for hypothesis 3 of $0.000<$ 0.05 means that there is a perceived behavioral control effect on the intention to shop online. The p-value for hypothesis 4 of $0.000<0.05$ means that there is an impact of intention to shop online on online shopping behavior.

\section{Discussion}

Hypothetical test outcome 1 there is an impact attitude on intention to shop online. These outcomes are in accordance with [13] which concluded that attitude affects intention to shop online. Attitude is the level at which a person has a positive or negative assessment of a particular conduct. When buyers think that the use of e-business is not crucial, an attitude is formed that makes buyers do not intend to use e-business. On the contrary, if buyers think that the use of ebusiness is a necessity, then there will be a positive attitude, in addition, if buyers think that ebusiness can provide benefits to obtain more effective goods search and greater discounts then buyers will intend to use e-business.

Hypothetical test outcome 2 there is no effect subjective norm on intention to shop online. These outcomes do not match [13] which concluded that subjective norm has an effect on the intention to shop online. buyer subjective norms for the use of e-business are formed from the surrounding environment. When other buyers in the neighbourhood do not use e-business and 
still use direct shopping, subjective norms are formed that make buyers do not intend to use ebusiness. Conversely, if people around such as friends or family recommend using e-business, and the transaction process goes well then subjective norms are formed that make buyers intend to use e-business.

Hypothetical test outcomes 3 there is an impact of perceived behavioral control on intention to shop online. These outcomes are in accordance with [13] which concluded that perceived behavioral control affects intention to shop online. Behavioral control is a condition in which a person believes that an action is easy or difficult to do under the management of the person. When the use of e-business is difficult to use, then a behavioral control is formed that makes buyers do not intend to use e-business. On the contrary, if buyers think that e-business is easy to use, a positive orientation will be formed.

Hypothetical test outcomes 4 there is an impact of intention to shop online on online shopping behavior. These outcomes are in accordance with [13] which concluded that intention to shop online affects online shopping behavior. Intention to shop online is able to produce online shopping behavior from the interests experienced by buyers. At the stage of interest, buyers realize that they like a particular goods and want to own the goods so that if the thought in the goods are positive it will lead to the decision to make a purchase behavior. Intention to shop online is a variable that affects online shopping behavior.

\section{Conclusion}

Indonesian people's awareness of e-business is still low, many people do not know how to utilize it. this study aims to test whether attitudes, subjective norms, perceived behavioral controls affect the buyer's intention to shop online, and then there will be the process of translating into buyer conduct to shop online.

There is an impact attitude on intention to shop online. Buyers think that the utilize of $e-$ business is a necessity, then there will be a positive attitude. There is no effect subjective norm on intention to shop online. Other buyers in the neighbourhood do not utilize e-business and still utilize direct shopping, subjective norms are formed that make buyers do not intend to utilize ebusiness. There is an impact of perceived behavioral control on intention to shop online. Buyers think that e-business is easy to utilize, a positive orientation will be formed.

This study can not find the way how subjective norm can affect intention to shop online. Further study is recommended to seek it. sample addition is recommended to see how theory of planned behavior affect shopping online behavior.

\section{REFERENCES}

[1] U. Can and B. Alatas, "Big social network data and sustainable economic development," Sustainability, vol. 9, no. 11, p. 2027, 2017.

[2] M. Z. Ngoasong, "Digital entrepreneurship in a resource-scarce context: A focus on entrepreneurial digital competencies," J. Small Bus. Enterp. Dev., 2018.

[3] M. T. Toukabri and S. A. Ettis, "The Acceptance and Behavior Towards E-Insurance," Int. J. E-bus. Res., vol. 17, no. 2, pp. 24-39, 2021.

[4] F. T. C. Tan, S. L. Pan, and M. Zuo, "Realising platform operational agility through information technology-enabled capabilities: A resource-interdependence perspective," Inf. Syst. J., vol. 29, no. 3, pp. 582-608, 2019.

[5] J. G Kabira, "E-Business," 2018.

[6] M. F. ljaz and J. Rhee, "Constituents and consequences of Online-shopping in Sustainable E-Business: An experimental study of Online-Shopping Malls," Sustainability, vol. 10, no. 10, p. 3756, 2018.

[7] Kusnadi, C. Lukita, N. Lutfiani, H. Lutfilah Juniar, and U. Rahardja, "Miu ai: Application based on the e-commerce prototype for japanese otaku in indonesia," J. Adv. Res. Dyn. Control Syst., vol. 12, no. 6, pp. 618-623, 2020, doi: 10.5373/JARDCS/V12I6/S20201071.

[8] D. R. P. P. Nida, I. M. D. S. Wirawan, and I. M. D. Harmana, "The Influencing Factors toward Universitas Warmadewa Student Interests in Using Mobile Commerce," J. Ekon. Bisnis JAGADITHA, vol. 7, no. 2, pp. 104-113, 2020.

[9] C. S. Bangun and T. Handra, "How Theory of Planned Behavior And Perceived Risk 
Affect Online Shopping Behavior," Aptisi Trans. Manag., vol. 5, no. 2, pp. 169-179, 2021.

[10] L. Netzer, T. Gutentag, M. Y. Kim, N. Solak, and M. Tamir, "Evaluations of emotions: Distinguishing between affective, behavioral and cognitive components," Pers. Individ. Dif., vol. 135, pp. 13-24, 2018.

[11] S. B. Ferraz, C. Buhamra, M. Laroche, and A. R. Veloso, "Green products: A crosscultural study of attitude, intention and purchase behavior," RAM. Rev. Adm. Mackenzie, vol. 18, pp. 12-38, 2017.

[12] S. Sayyida, S. Hartini, S. Gunawan, and S. N. Husin, "The Impact of the Covid-19 Pandemic on Retail Consumer Behavior," Aptisi Trans. Manag., vol. 5, no. 1, pp. 79-88, 2021.

[13] N. Peña-García, I. Gil-Saura, A. Rodríguez-Orejuela, and J. R. Siqueira-Junior, "Purchase intention and purchase behavior online: A cross-cultural approach," Heliyon, vol. 6, no. 6, p. e04284, 2020.

[14] W. Liu, R. Batra, and H. Wang, "Product touch and consumers' online and offline buying: the role of mental representation," J. Retail., vol. 93, no. 3, pp. 369-381, 2017.

[15] V. M. Sharma and A. Klein, "Consumer perceived value, involvement, trust, susceptibility to interpersonal influence, and intention to participate in online group buying," J. Retail. Consum. Serv., vol. 52, p. 101946, 2020.

[16] S. Chung, T. Kramer, and E. M. Wong, "Do touch interface users feel more engaged? The impact of input device type on online shoppers' engagement, affect, and purchase decisions," Psychol. Mark., vol. 35, no. 11, pp. 795-806, 2018.

[17] W. A. Novalia Agung, "The Impact of Interpersonal Communication toward Customer Satisfaction: The Case of Customer Service of Sari Asih Hospital," MATEC Web Conf., vol. 150, 2018.

[18] T. Wright et al., "Charity-oriented versus human resource-oriented perspectives: Investigating staff understandings of employment practices for persons with disabilities," J. Appl. Rehabil. Couns., vol. 51, no. 2, pp. 146-167, 2020.

[19] X. Ru, S. Wang, and S. Yan, "Exploring the effects of normative factors and perceived behavioral control on individual's energy-saving intention: An empirical study in eastern China," Resour. Conserv. Recycl., vol. 134, pp. 91-99, 2018.

[20] I. Ajzen, "The theory of planned behavior: Frequently asked questions," Hum. Behav. Emerg. Technol., vol. 2, no. 4, pp. 314-324, 2020.

[21] D. D. Woods, "Decomposing automation: Apparent simplicity, real complexity," in Automation and human performance: Theory and applications, CRC Press, 2018, pp. 317. 